\title{
Modification of Chitosan by Zincke Reaction: Synthesis of a Novel Polycationic Chitosan-Pyridinium Derivative
}

\author{
Fernanda J. Gonçalves ${ }^{a}$ and Rossimiriam P. Freitas ${ }^{(*, a}$ \\ ${ }^{a}$ Departamento de Química, Instituto de Ciências Exatas (ICEx), \\ Universidade Federal de Minas Gerais (UFMG), Av. Pres. Antônio Carlos, 6627, \\ Pampulha, 31270-901 Belo Horizonte-MG, Brazil
}

\begin{abstract}
Chitosan is a biodegradable aminopolysaccharide produced by deacetylation of acetamide groups of chitin, one of the most abundant organic materials in nature. Many different types of organic reactions have been described to modify the functional groups of chitosan and produce materials with applications in a large number of areas. However, the Zincke reaction, an old method which is commonly used to convert primary amine in pyridinium salts, has not been reported to transform the chitosan amino group at C-2 position in glucosamine units. In this paper, our efforts are described to carry out this reaction, employing different conditions to covalently anchor pyridinium salts on the polymer surface. Optimized synthesis conditions using water/ethanol as solvent, triethylamine and Zincke salt excess yielded a novel polycationic chitosan-pyridinium derivative with a weight gain of $52 \%$ after $48 \mathrm{~h}$ of reaction. The modified biopolymer is water insoluble and exhibits a high degree of chemical modification. The ${ }^{13} \mathrm{C}$ solid state nuclear magnetic resonance (SS-NMR) spectrum of chitosan-pyridinium derivative showed signals at 147.0, 142.0 and $129.0 \mathrm{ppm}$, attributed to aromatic carbons, confirming the presence of a quaternary pyridinium ring directly attached to the biopolymer. The Zincke reaction was employed for the first time to modify the chitosan backbone.
\end{abstract}

Keywords: chitosan, Zincke reaction, pyridinium salts

\section{Introduction}

Chitosan, a carbohydrate biopolymer composed of $\beta(1 \rightarrow 4)$ linked units of $N$-acetyl- $D$-glucosamine and $D$-glucosamine (Figure 1), is classically obtained by the controlled deacetylation of chitin, the second most abundant natural polysaccharide after cellulose. ${ }^{1}$ For several decades, partly due to its abundance and biofunctionality, chitosan has been widely studied. ${ }^{2}$ Moreover, this polymer displays interesting properties such as biodegradability, biocompatibility, low toxicity and great potential for chemical modification, providing an exciting platform for the development of different materials with various physicochemical properties. ${ }^{3}$ A great number of modulated chemical reactions may be performed on chitosan C-2 free amino and C-3 and C-6 hydroxyl groups, ${ }^{4}$ yielding novel polymers with applications in different fields such as biomedicine, ${ }^{5}$ environmental chemistry, ${ }^{6}$ agriculture, ${ }^{7}$ biotechnology industry, ${ }^{8}$ food products, ${ }^{9}$ molecular biology, ${ }^{10}$ etc. The most common chitosan chemical modifications

*e-mail: rossimiriam@qui.ufmg.br include $N$-phthaloylation, $N$-carboxyalkylation, $N$ and/or $O$-acylation/alkylation, $O$-carboxymethylation, quaternization, Schiff base formation, phosphorylation, graft copolymerization, $O$-sulfonation, among others. ${ }^{11}$

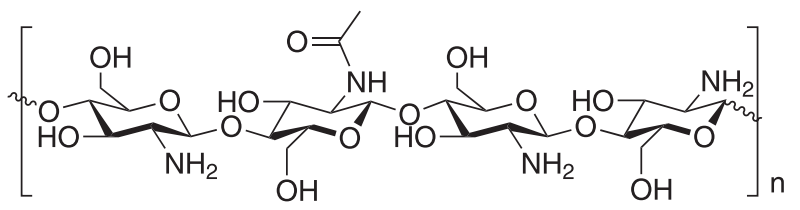

Figure 1. Chemical structure of chitosan.

Pyridinium salts represent a versatile class of heterocycles found in many natural and synthetic bioactive compounds. ${ }^{12}$ These cationic substances have demonstrated biological uses in drug delivery and gene therapy. ${ }^{13}$ They may also act as antimicrobial agents ${ }^{13}$ and enzyme inhibitors, ${ }^{14}$ among other applications. Furthermore, these salts have been employed as phase transfer catalysts,,${ }^{15}$ ionic liquids ${ }^{16}$ and cationic polymerization initiators. ${ }^{17}$ These quaternary compounds are commonly used as important intermediates in organic synthesis for the preparation 
of highly complex nitrogenous substances, including $\mathrm{N}$-substituted dihydropyridines, tetrahydropyridines and hexahydropyridines. ${ }^{14}$

The most common method to prepare pyridinium salts is the alkylation of the pyridine nitrogen atom with primary alkylating agents by an $\mathrm{S}_{\mathrm{N}} 2$ reaction. ${ }^{18}$ However, in special cases (for example in the synthesis of $\mathrm{N}$-arylpyridinium or pyridinium salts containing a chiral group which presents a significant risk of racemization during alkylation), ${ }^{14}$ the best choice is the reaction between primary amines with highly electrophilic species, such as pyrylium ${ }^{19}$ or Zincke salts $\left(N\right.$-2,4-dinitrophenyl-pyridinium salt). ${ }^{20}$ The latter salt, which may be prepared via $\mathrm{SN}_{\mathrm{Ar}}$ from pyridine and 2,4-dichloronitrobenzene (Scheme 1), ${ }^{21}$ is an important starting material for the Zincke reaction. In this reaction, the salt suffers an attack at the pyridinium C-2 atom by the primary amines and generates a new pyridinium derivative through a transannulation reaction. In sum, the nitrogen atom of the primary amine is incorporated in the pyridine cycle without $\mathrm{C}-\mathrm{N}$ amine bond cleavage. ${ }^{14}$

Despite the great number of chitosan derivatives synthesized up to date and the variety of primary amines employed as starting materials for the Zincke reaction, no reports have been made so far in the literature describing the synthesis and characterization of covalently anchored pyridinium salt into chitosan backbone using the electrophilic Zincke salt. Considering the experience of our group in the Zincke chemistry ${ }^{12}$ and the interest on the obtention of a novel polycationic chitosan-based material with potential biological applications, this paper describes our efforts to evaluate the viability of this reaction to chemically modify chitosan.

\section{Experimental}

Materials

Medium molecular weight chitosan (75-85\% deacetylated, Sigma-Aldrich, Brazil), pyridine (Vetec, Brazil), 1-chloro-2,4-dinitrobenzene (Sigma-Aldrich,
Brazil), triethylamine $\left(\mathrm{Et}_{3} \mathrm{~N}\right)$ (Dinâmica, Brazil), acetone (CRQ, Brazil), ethanol (95\%, Labsynth, Brazil), $\mathrm{NaOH}$ and $\mathrm{HCl}$ were used in this study.

\section{Synthesis of a chitosan-pyridinium derivative (C1)}

The Zincke salt was prepared according to Vianna et al. ${ }^{12}$ Chitosan $\left(0.5 \mathrm{~g}, 2.5 \mathrm{mmol}\right.$ of $\left.\mathrm{NH}_{2}\right)$, Zincke salt (1.125 g, $4 \mathrm{mmol}, 1.6$ equiv.) and $20.0 \mathrm{~mL}$ of ethanol/distilled water (1:1) were added to a $250 \mathrm{~mL}$ round-bottom flask, then $4 \mathrm{mmol}$ (1.6 equiv.) of triethylamine was added. The reaction mixture was refluxed at $100{ }^{\circ} \mathrm{C}$ with magnetic stirring for $48 \mathrm{~h}$. At the end of the reaction, the suspension was separated by vacuum filtration using a Büchner funnel, and the modified chitosan $(\mathbf{C 1})$ was washed with ethanol, dichloromethane, distilled water and exhaustively with acetone, then $\mathbf{C 1}$ was dried in an oven at $70^{\circ} \mathrm{C}$ for $1 \mathrm{~h}$.

\section{Percent weight gain (pwg)}

The pwg after modification of chitosan with Zincke salt was calculated using equation 1 .

$\operatorname{pwg}(\%)=\left(\frac{\mathrm{w}_{\mathrm{cl}}-\mathrm{w}_{\mathrm{c}}}{\mathrm{w}_{\mathrm{c}}}\right) \times 100$

where $\mathrm{w}_{\mathrm{c}}(\mathrm{g})$ and $\mathrm{w}_{\mathrm{cl}}(\mathrm{g})$ are the weights of the chitosan and $\mathbf{C 1}$, respectively.

Determination of degree of deacetylation (DD) and amount of free amine groups $\left(\mathrm{n}_{\mathrm{NH}_{2}}\right)$ of chitosan

The DD (in percentage) and $\mathrm{n}_{\mathrm{NH}_{2}}\left(\mathrm{mmol} \mathrm{g}{ }^{-1}\right.$ ) of chitosan were determined by potentiometric titration. A sample of $25.0 \mathrm{mg}$ of chitosan was dissolved in $25.0 \mathrm{~mL}$ of standardized aqueous $\mathrm{HCl}$ solution $\left(0.1 \mathrm{~mol} \mathrm{~L}^{-1}\right)$, after complete dissolution that solution was titrated with standardized aqueous $\mathrm{NaOH}$ solution $\left(0.1 \mathrm{~mol} \mathrm{~L}^{-1}\right)$. A pH meter (PHS-3BW, Aprolab, Brazil) was used for $\mathrm{pH}$ measurements, three replicates were performed. The degree of deacetylation was calculated<smiles>[R]c1ccc(-c2ccc([N+](=O)[O-])c([N+](=O)[O-])c2)cc1</smiles>

Zincke salt

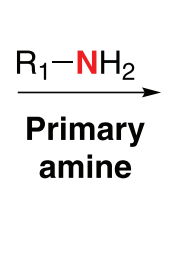

\section{Pyridinium \\ salt}


by equation $2^{22,23}$ and the amount of free amine groups was calculated using equation $3 .^{24}$

$\mathrm{DD}(\%)=\frac{\mathrm{V}_{\mathrm{NaOH}} \times \mathrm{C}_{\mathrm{NaOH}} \times 0.016}{0.0994 \times \mathrm{w}_{\mathrm{c}}}$

$\mathrm{n}_{\mathrm{NH}_{2}}\left(\mathrm{mmol} \mathrm{L}^{-1}\right)=\frac{\mathrm{C}_{\mathrm{NaOH}} \times \mathrm{V}_{\mathrm{NaOH}}}{\mathrm{w}_{\mathrm{c}}}$

where $\mathrm{V}_{\mathrm{NaOH}}(\mathrm{mL})$ is the volume of aqueous $\mathrm{NaOH}$ solution required to neutralize the ammonium groups, $\mathrm{C}_{\mathrm{NaOH}}$ $\left(\mathrm{mol} \mathrm{L}^{-1}\right)$ is the concentration of aqueous $\mathrm{NaOH}$ solution, 0.016 is the molar mass weight of $\mathrm{NH}_{2}\left(\mathrm{~kg} \mathrm{~mol}^{-1}\right)$ and 0.0994 is the theoretical $\mathrm{NH}_{2}$ percentage in chitosan. ${ }^{25}$

\section{Fourier transform infrared spectroscopy (FTIR) analysis}

Chitosan and $\mathbf{C 1}$ were analyzed by FTIR spectroscopy. Samples were dried in an oven at $70^{\circ} \mathrm{C}$ for $1 \mathrm{~h}$, then $1.0 \mathrm{mg}$ of each material was mixed with $100.0 \mathrm{mg}$ of spectroscopy grade $\mathrm{KBr}$. The FTIR spectra were recorded on a Shimadzu IR-408 spectrometer (ICEx-DQ, UFMG, Brazil), with the detector at a resolution of $4 \mathrm{~cm}^{-1}$, from 400 to $4000 \mathrm{~cm}^{-1}$ and 32 scans per sample.
Solid state ${ }^{13} \mathrm{C}$ nuclear magnetic resonance (NMR) analysis

The solid-state ${ }^{13} \mathrm{C}$ NMR spectrum of $\mathbf{C 1}$ was obtained on a Varian-Agilent $400 \mathrm{MHz}$ spectrometer (NCQP, UFES, Brazil) at the frequency of $100 \mathrm{MHz}$, acquisition time of $20.48 \mathrm{~ms}$, with an accumulation of 1232 scans.

\section{Results and Discussion}

The Zincke salt ( $N$-2,4-dinitrophenyl-pyridinium salt) was easily prepared by the reaction between pyridine and 1-chloro-2,4-dinitrobenzene under acetone reflux for $15 \mathrm{~h}$, following an $\mathrm{SN}_{\mathrm{Ar}}$ mechanism. ${ }^{12}$ The next stage was the treatment of chitosan with 1 equivalent of the Zincke salt in refluxing 1-butanol for $15 \mathrm{~h}$, an ideal condition established by Marazano and co-workers. ${ }^{20}$ In these heterogeneous conditions, no change from the original color of the suspension was observed, even prolonging the reaction time or adding $\mathrm{Et}_{3} \mathrm{~N}$ to enhance the nucleophilic properties of the amino groups (Table 1, entries 1-3). Thus, it was decided to study the reaction between $D$-glucosamine (the monomeric unit of chitosan) and the Zincke salt since a thorough search of the literature revealed that no carbohydrate-based pyridinium salts were

Table 1. Conditions tested for the synthesis of $\mathbf{C} \mathbf{1}$ via Zincke reaction

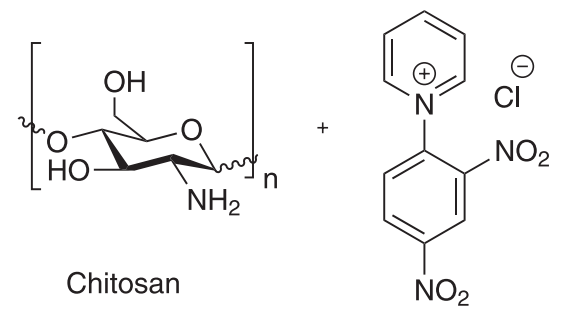

Zincke salt

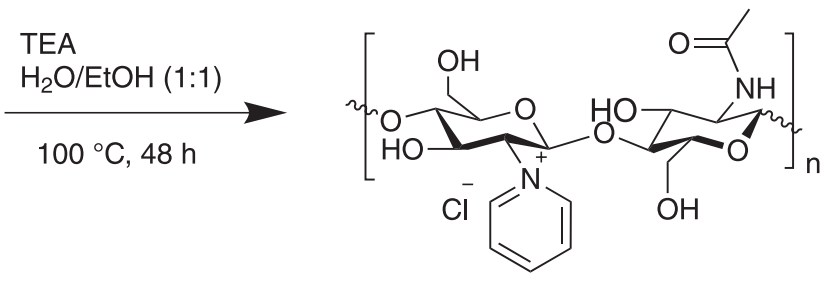

$\mathbf{C}_{1}$

\begin{tabular}{|c|c|c|c|c|c|c|c|}
\hline Reaction & Solvent & time / h & Temperature $/{ }^{\circ} \mathrm{C}$ & $\mathrm{Et}_{3} \mathrm{~N} /$ equiv. & Zincke salt / equiv. & Heating & pwg / \% \\
\hline 1 & $n$-butanol & 15 & 115 & - & 1.6 & conventional & 0 \\
\hline 2 & $n$-butanol & 36 & 115 & - & 1.6 & conventional & 2.3 \\
\hline 3 & $n$-butanol & 48 & 115 & 1.6 & 1.6 & conventional & 0 \\
\hline 4 & $\mathrm{H}_{2} \mathrm{O}$ & 48 & 100 & 1.6 & 1.6 & conventional & 35.5 \\
\hline 5 & $\mathrm{H}_{2} \mathrm{O}$ & $15 \mathrm{~min}$ & 100 & - & 1.6 & microwave & 0 \\
\hline 6 & $\mathrm{H}_{2} \mathrm{O} / \mathrm{EtOH}(20: 80)$ & 1 & 100 & 1.6 & 3 & ultrasound & 2 \\
\hline 7 & $\mathrm{H}_{2} \mathrm{O} / \mathrm{EtOH}(20: 80)$ & 48 & 100 & 1.6 & 1.6 & conventional & 18.4 \\
\hline 8 & $\mathrm{H}_{2} \mathrm{O} / \mathrm{EtOH}(20: 80)$ & 48 & 100 & 1.6 & 3 & conventional & 30 \\
\hline 9 & $\mathrm{H}_{2} \mathrm{O} / \mathrm{EtOH}(50: 50)$ & 48 & 100 & 1.6 & 3 & microwave & 17 \\
\hline 10 & $\mathrm{H}_{2} \mathrm{O} / \mathrm{EtOH}(50: 50)$ & 48 & 100 & 1.6 & 1.6 & conventional & 52 \\
\hline 11 & $\begin{array}{c}\mathrm{H}_{2} \mathrm{O} / \mathrm{EtOH}(50: 50) \\
1 \% \mathrm{AcOH}\end{array}$ & 48 & 100 & 1.6 & 1.6 & conventional $^{\mathrm{a}}$ & 25 \\
\hline 12 & $\begin{array}{l}\text { AcOH-AcO-/EtOH (50:50) } \\
\text { (buffer pH 4.5) }\end{array}$ & 48 & 100 & - & 1.6 & conventional $^{\mathrm{a}}$ & 28 \\
\hline 13 & $\begin{array}{c}\text { AcOH-AcO-/EtOH (50:50) } \\
\text { (buffer pH 4.5) }\end{array}$ & 48 & 100 & 1.6 & 1.6 & conventional $^{\mathrm{a}}$ & 34 \\
\hline
\end{tabular}

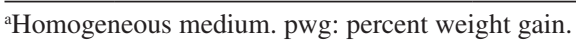


efficiently prepared by the Zincke reaction. However, all conditions used to promote this reaction did not provide the desired pyridinium salt, suggesting that the amino group in glucosamine is a poor nucleophile to pyridinium salts, probably by steric hindrance. Rivard and co-workers ${ }^{18}$ described the use of water as a solvent to promote the reaction of poorly nucleophilic amines with Zincke salts. Thus, in our hands, the use of water (Table 1, entry 4) resulted in an immediate formation of a deep red color in the reaction (Figure 2), indicating a facile and rapid formation of dianil salts, important intermediates in the Zincke reaction. After $48 \mathrm{~h}$, the red color disappeared, and the reaction medium turned brown. (a)

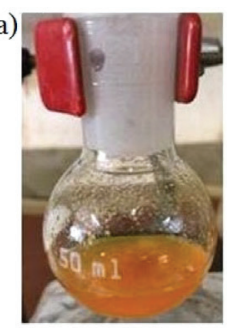

(b)

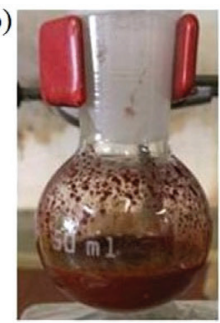

(c)

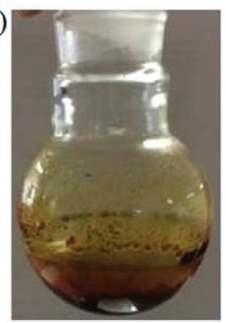

Figure 2. Reaction between chitosan and Zincke salt: (a) initial time; (b) $30 \mathrm{~min}$; (c) $48 \mathrm{~h}$.

After filtration and exhaustive washing with different solvents to remove the unreacted Zincke salt and the 2,4-dinitroaniline formed in the reaction, the obtained solid was dried under vacuum and characterized by usual spectral techniques. The percent weight gain of this material was $35.5 \%$, indicating an important chemical modification degree. Other conditions were evaluated to increase the percent weight gain of the chitosan material, including the use of microwave (Table 1, entry 5), ultrasound (Table 1, entry 6), a binary solvent system (entries 6-11) and homogeneous reaction conditions (entries 11-13). In the case of microwave assisted reaction, it was observed the rapid formation of red dianil salts, but the suspension color indicated that the ring closure step was too slow to be observed. The system employing the binary solvent water/ ethanol, amine and Zinke salt excess for $48 \mathrm{~h}$ at $100{ }^{\circ} \mathrm{C}$ provided the highest percent mass gain. The polycationic obtained material $\mathbf{C} \mathbf{1}$ was insoluble in organic solvents and in aqueous media in $\mathrm{pH}$ ranges 1-12, being soluble only in concentrated nitric acid at room temperature.

The Zincke reaction follows an $\mathrm{S}_{\mathrm{N}}($ ANRORC) mechanism with three key steps: nucleophilic addition, ring opening, and ring closing with a key cis-trans interconversion (Scheme 2). ${ }^{26}$ In detail: the nucleophilic attack of the primary amine leads to the ring opening of the pyridinium ring; a second equivalent of the primary amine carries out a new nucleophilic attack causing the displacement of 2,4-dinitroaniline and formation of the

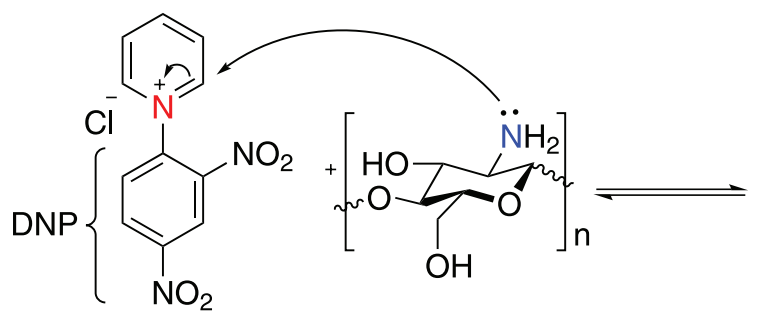

Zincke salt
Chitosan

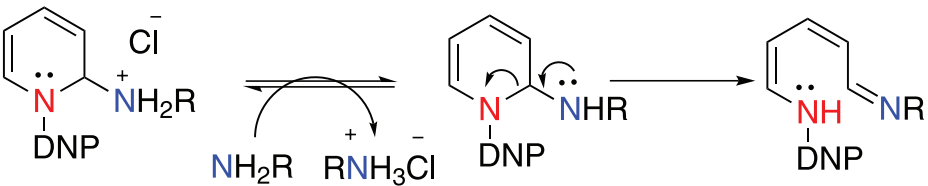<smiles>N[18O]C1CCC([Si]N)C1</smiles>

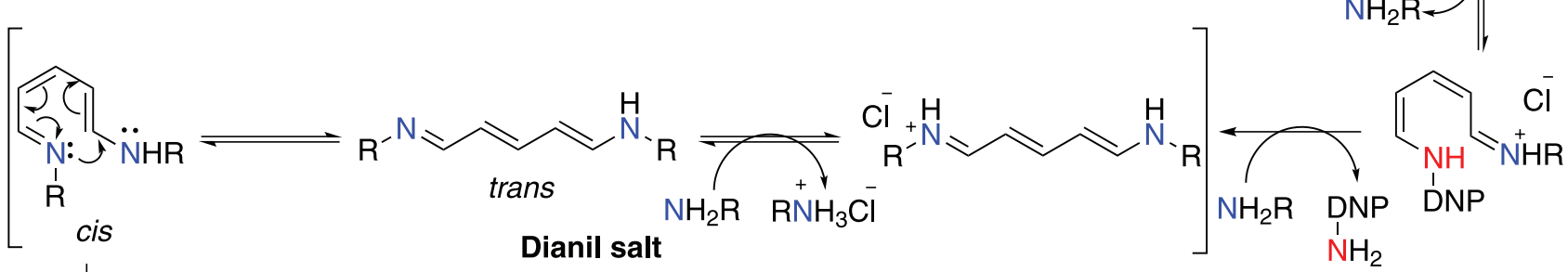

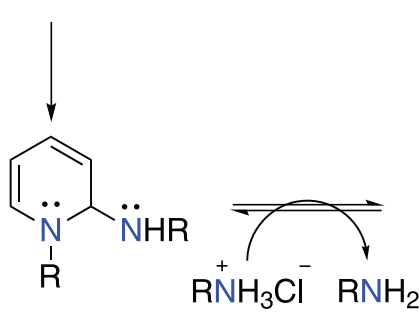

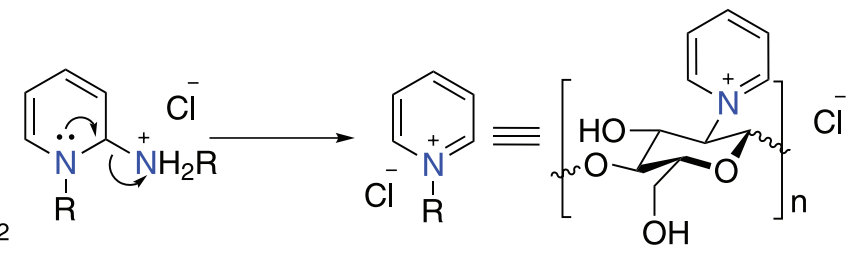

C1

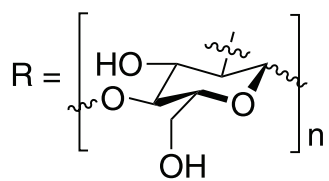

Scheme 2. Mechanism of the Zincke reaction. 
intense red dianil salts in equilibrium; $;{ }^{27}$ the interconversion process of trans dianil salt to cis is a fundamental step preceding ring closure. ${ }^{28}$ The trans-cis-trans isomer of the dianil salt can react by either nucleophilic addition or sigmatropic rearrangement of a zwitterionic intermediate to yield a cyclized intermediate..$^{28}$ The cyclization step seems to be the rate-determining of the reaction. The last step restores the aromaticity with the leaving of an amino group, and the novel pyridinium salt is formed.

Figure 3 shows the FTIR spectra of chitosan and C1. The main differences highlighted in the spectrum of $\mathbf{C 1}$ in comparison with chitosan are: (i) the bands at 1604 and $1560 \mathrm{~cm}^{-1}$, which can be attributed to the stretching of $\mathrm{C}=\mathrm{C}$ bonds; (ii) the appearance of bands at 1490 and $1432 \mathrm{~cm}^{-1}$, attributed to the stretching of $\mathrm{C}=\mathrm{N}$ bonds; and (iii) a band at $836 \mathrm{~cm}^{-1}$, related to the out-of-plane bending of $\mathrm{C}-\mathrm{H}$ in the pyridine ring. ${ }^{29}$ These changes indicate the introduction of the pyridine ring in chitosan. In addition, the absence of bands in the region of 1540 and $1340 \mathrm{~cm}^{-1}$, attributed to the asymmetric and symmetric stretching vibration of $\mathrm{NO}_{2}$ group,$^{30}$ in the spectrum of $\mathbf{C 1}$, indicates that this material is free of by-product 2,4-dinitroaniline.

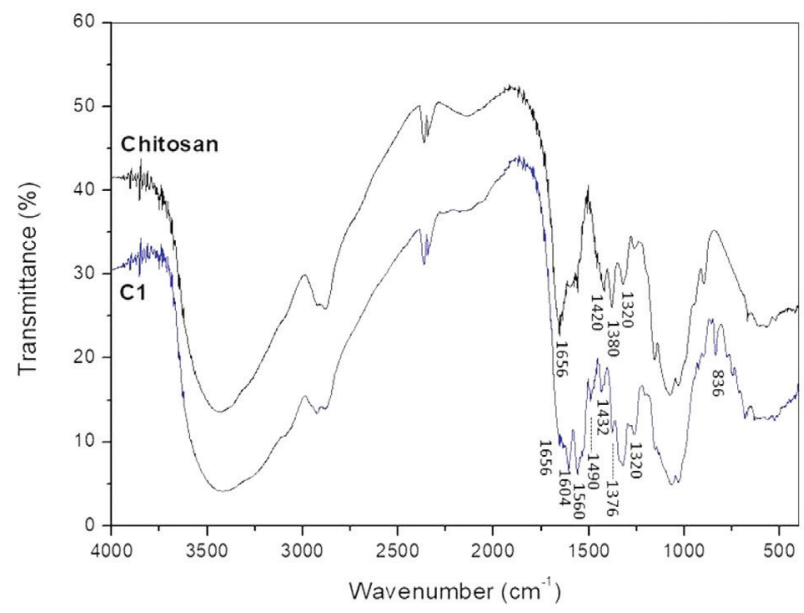

Figure 3. FTIR (KBr) spectra of chitosan and $\mathbf{C 1}$.

The solid-state ${ }^{13} \mathrm{C}$ NMR spectra of chitosan ${ }^{28}$ and $\mathbf{C 1}$ are shown in Figure 4. The spectrum of chitosan shows characteristic signals at 179.2 and 105.4 ppm corresponding to carbonyl and anomeric carbons, respectively. The signals at $57.3,60.9$, and $81.8 \mathrm{ppm}$ are attributed to the carbon atoms $\mathrm{C} 2, \mathrm{C} 6$ and $\mathrm{C} 4$ in pyranose rings. The signal at $75.9 \mathrm{ppm}$ can be assigned to the superposition of $\mathrm{C} 3$ and $\mathrm{C} 5$ resonances, and the signal at 22.5 is attributed to $\mathrm{C} 8 .^{31} \mathrm{After}$ modification of chitosan with Zincke salt, new resonances above $120 \mathrm{ppm}$ were observed. The signal at $147.0 \mathrm{ppm}$ is assigned to $\mathrm{Cc}$, an aromatic atom characteristically deshielded in pyridinium salts. ${ }^{26}$ The resonances signals at 129.0 and $142.0 \mathrm{ppm}$ are expected and can be easily assigned to $\mathrm{Cb}$ and $\mathrm{Ca}$, respectively. This set of signals is very important to confirm the presence of a quaternary pyridinium ring directly attached to the backbone of chitosan in $\mathbf{C 1}$.

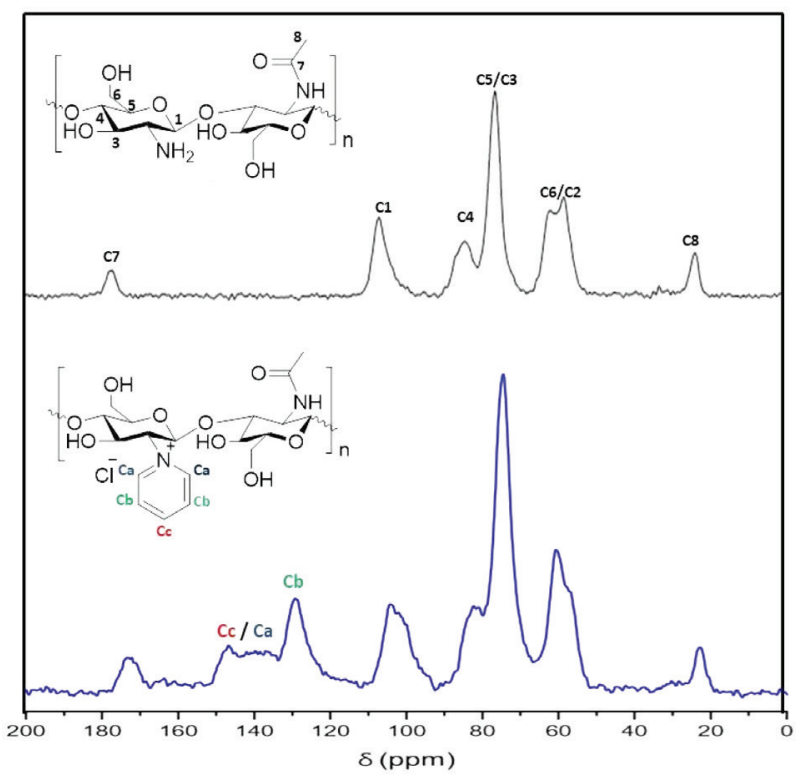

Figure 4. Solid-state ${ }^{13} \mathrm{C}$ NMR (100 MHz) of chitosan and $\mathbf{C 1}$.

\section{Conclusions}

The functionalization of chitosan using the Zincke reaction produced a novel water insoluble polycationic chitosan-pyridinium derivative. A number of conditions were tried to carry out the reaction between the carbohydrate biopolymer and the Zincke salt and the use of water as solvent resulted in a high degree of chemical modification. A high percent weight gain $(52 \%)$ was obtained using a reaction time of $48 \mathrm{~h}$ and a binary system of solvent with an excess of triethylamine and Zincke salt. C1 was characterized with success using FTIR and solid state ${ }^{13} \mathrm{C}$ NMR spectroscopies. It is the first time that the Zincke reaction is used to functionalize chitosan, incorporating the nitrogen atom of the amino group into a pyridinium cycle.

\section{Acknowledgments}

The authors are grateful to Fundação de Amparo à Pesquisa do Estado de Minas Gerais (FAPEMIG) for funding this research. The authors are also grateful to Conselho Nacional de Desenvolvimento Científico (CNPq) and Coordenação Aperfeiçoamento de Pessoal de Nível Superior (CAPES) for fellowships to F. J. G. and R. P. F. We kindly acknowledge Dr Jair C. C. Freitas and 
Daniel F. Cipriano (UFES) for providing the solid-state NMR spectrum.

\section{References}

1. Kaur, S.; Dhillon, G. S.; Crit. Rev. Microbiol. 2013, 40, 155.

2. Kinidri, H. E.; Belaabed, R.; Addaou, A.; Laajeb, A.; Lahsini, A.; Int. J. Biol. Macromol. 2018, 120, 1181.

3. Madera-Santana, T. J.; Herrera-Méndez, C. H.; Rodrígez-Núnez, J. R.; Green Mater. 2018, 6, 131.

4. Arguelles-Monal, W. M.; Lizardi-Mendoza, J.; FernándezQuiroz, D.; Recillas-Mota, M. T.; Montiel-Herrera, M.; Polymers 2018, 10, 342.

5. Li, J.; Wu, Y.; Zhao, L.; Carbohydr. Polym. 2016, 148, 200; Brasil, M. S. L.; Filgueiras, A. L.; Campos, M. B.; Neves, M. S. L.; Eugênio, M.; Sena, L. A.; Sant'Anna, C. B.; da Silva, V. L.; Diniz, C. G.; Sant'Anna, A. C.; J. Braz. Chem. Soc. 2018, 29, 2026.

6. Gonçalves, J. O.; Santos, J. P.; Rios, E. C.; Cispim, M. M.; Dotto, G. L.; Pinto, L. A. A.; J. Mol. Liq. 2017, 225, 265.

7. Maruyama, C. R.; Guilger, M.; Pascoli, M.; Bileshy-José, N.; Abhilash, P. C.; Fraceto, L. F.; Lima, R.; Sci. Rep. 2016, 6, 19768.

8. Vilela, C.; Pinto, R. J. B.; Coelho, J.; Domingues, M. R. M.; Daina, S.; Sadocco, P.; Santos, S. A. O.; Freire, C. S. R.; Food Hydrocolloids 2017, 73, 120.

9. Albdelmalek, B. E.; Sila, A.; Haddar, A.; Bougatef, A.; Ayadi, M. A.; Int. J. Biol. Macromol. 2017, 104, 953.

10. Janagam, D. R.; Wu, L.; Lowe, T. L.; Adv. Drug Delivery Rev. 2017, 122, 31 .

11. Sajid, M. A.; Shahzad, S. A.; Hussain, F.; Skene, W. G.; Khan, Z. A.; Yar, M.; Synth. Commun. 2018, 48, 1893.

12. Vianna, G. H. R.; Santos, I. C.; Freitas, R. P.; Gil, L. F.; Alves, R. B.; Lett. Org. Chem. 2008, 5, 396.

13. Furdui, B.; Parfene, G.; Ghinea, I. O.; Dinica, R. M.; Bahrim, G.; Demeunynck, M.; Molecules 2014, 19, 11572.

14. Baharloo, F.; Moslemin, M. H.; Nadri, H.; Asadipour, A.; Mahdavi, M.; Emami, S.; Firoozpour, L.; Mohebat, R.; Shafiee, A.; Foroumadi, A.; Eur. J. Med. Chem. 2015, 93, 196.

15. Sowmiah, S.; Esperança, J. M. S. S.; Rebelo, L. P N.; Afonso, C. A. M.; Org. Chem. Front. 2018, 5, 453.
16. Pendleton, J. N.; Gilmore, B. F.; Int. J. Antimicrob. Agents 2015 , 46, 131.

17. Dadashi-Silab, S.; Doran, S.; Yagci, Y.; Chem. Rev. 2016, 116, 10212.

18. Zeghbib, N.; Thelliere, P.; Rivard, M.; Martens, T.; J. Org. Chem. 2016, 81, 3256.

19. Franconetti, A.; Contreras-Bernal, L.; Prado-Gotor, R.; CabreraEscribano, F.; RSC Adv. 2015, 5, 74274.

20. Genisson, Y.; Marazano, C.; Mehmandoust, M.; Gnecco, D.; Das, B. C.; Synlett 1992, 43.

21. Vanderwal, C. D.; J. Org. Chem. 2011, 76, 9555.

22. Pang, K.; Ding, B.; Liu, X.; Wu, H.; Duan, Y.; Zhang, J.; Green Chem. 2017, 19, 3665.

23. Jiang, X.; Chen, L.; Zhong, W.; Carbohydr. Polym. 2003, 54, 457.

24. Raymond, L.; Morin, F. G.; Marchessault, R. H.; Carbohydr. Res. 1993, 246, 331.

25. Yuan, Y.; Chesnutt, B. M.; Haggard, W. O.; Bumgardner, J. D.; Materials 2011, 4, 1399.

26. Cheng, W.-C.; Kurth, M. J.; Org. Prep. Proced. Int. 2002, 34 , 585.

27. Das, G.; Skorjanc, T.; Sharma, S. K.; Gándara, F.; Lusi, M.; Rao, D. S. S.; Vimala, S.; Prasad, S. K.; Raya, J.; Han, D. S.; Jagannathan, R.; Oslen, J.-C.; Trabolsi, A.; J. Am. Chem. Soc. 2017, 139, 9558.

28. Marvell, E. N.; Caple, G.; Shahidi, I.; J. Am. Chem. Soc. 1970, $92,5641$.

29. Goncalves, F. J.; Kamal, F.; Gaucher, A.; Gil, R.; Bourdreux, F.; Martineau-Corcos, C.; Gurgel, L. V. A.; Gil, L. F.; Prim, D.; Carbohydr. Polym. 2018, 181, 1206.

30. Shankar, R. M.; Roy, T. K.; Jana, T.; J. Appl. Polym. Sci. 2009, 114, 732 .

31. Almeida, F. T. R.; Ferreira, B. C. S.; Moreira, A. L. S. L.; Freitas, R. P.; Gil, L. F.; Gurgel, L. V. A.; J. Colloid Interface Sci. 2016, 466, 297.

Submitted: February 15, 2019 Published online: June 11, 2019 